\section{Discoversys \\ Published by DiscoverSys \\ Relationship between Nurse Knowledge, Attitude, Workloads with Medical Record Completion at the Emergency Unit, Sanglah Hospital, Denpasar}

\author{
Putri Mastini, ${ }^{1,2^{*}}$ Nyoman Tigeh Suryadhi, ${ }^{2,3}$ Alit Suryani ${ }^{1,4}$
}

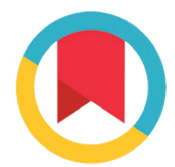

CrossMark

\begin{abstract}
Backgrounds and purpose: Accuracy and comprehensive maintenance of patient records is an integral part of nursing staff duties. Incomplete documentation could reduce the quality of care and service at the hospital. This study seeks to explore the relationship between nursing staff knowledge, attitude and workloads with accuracy of medical record maintenance at the Emergency Unit in Sanglah Hospital. Methods: Study was cross sectional with a sample of 76 nurses at Emergency Unit Sanglah Hospital. Nurses were interviewed on their knowledge, attitude and workloads. Data on accuracy and completion of medical record was obtained through direct observation.
\end{abstract}

Results: Accuracy and completion of documentation had a significant relationship with knowledge and nurse attitude $(p<0,05)$. Multivariate analysis indicated that nurse knowledge had a significant relationship in completing medical records with adjusted $\mathrm{OR}=3.7$ (95\% Cl: $1.2-$ 11.5). This finding indicated that nurses with a higher knowledge on the maintaining medical records was 3.7 times more likely to complete the required documentation compared to nurses with lower knowledge.

Conclusion: Accuracy and completion of patient documentation by nurses was significantly associated with their knowledge.

Key words: knowledge, attitude, workloads, nursing care

Cite This Article: Mastini, P., Suryadhi, N.T., Suryani, A. 2015. Relationship between Nurse Knowledge, Attitude, Workloads with Medical Record Completion at the Emergency Unit, Sanglah Hospital, Denpasar. Public Health and Preventive Medicine Archive 3(1): 40-43. D01:10.15562/phpma. v3i1.85

\title{
Hubungan Tingkat Pengetahuan, Sikap, Beban Kerja Perawat dengan Kelengkapan Dokumentasi Asuhan Keperawatan di IRNA IGD RSUP Sanglah Denpasar
}

\section{ABSTRAK}

Latar belakang dan tujuan: Dokumentasi asuhan keperawatan merupakan unsur pokok dalam pertanggung jawaban kinerja profesi keperawatan. Dokumentasi yang tidak lengkap akan berakibat pada penurunan kualitas pelayanan di rumah sakit. Penelitian ini bertujuan untuk mengetahui hubungan antara pengetahuan, sikap dan beban kerja perawat dengan kelengkapan pendokumentasian asuhan keperawatan di Ruang Rawat Inap Instalasi Gawat Darurat RSUP Sanglah Denpasar.

Metode: Survei cross sectional telah dilakukan terhadap semua perawat (76 sampel) yang bertugas di Ruang Rawat Inap Instalasi Gawat Darurat RSUP Sanglah Denpasar. Wawancara dengan perawat dilakukan untuk mendapatkan data tentang pengetahuan, sikap dan beban kerja. Data status kelengkapan pendokumentasian keperawatan diukur dengan metode observasi.

Hasil: Kelengkapan pendokumentasian asuhan keperawatan berhubungan secara signifikan dengan tingkat pengetahuan dan sikap perawat $(p<0,05)$. Analisis multivariat menunjukkan bahwa tingkat pengetahuan memiliki pengaruh terbesar dengan kelengkapan pendokumentasian asuhan keperawatan dengan adjusted $\mathrm{OR}=3,7$ (95\%Cl: 1,2-11,5). Hal ini berarti pendokumentasian asuhan keperawatan yang lengkap pada perawat dengan pengetahuan baik 3,7 kali dibandingkan dengan perawat yang memiliki pengetahuan kurang. Simpulan: Kelengkapan pendokumentasian asuhan keperawatan secara bermakna berhubungan dengan tingkat pengetahuan perawat.
*Correspondence to: Putri Mastini, Sanglah General Public Hospital Denpasar, Public Health Postgraduate Program Udayana University

agung.putri51@gmail.com
Kata kunci: tingkat pengetahuan, sikap, beban kerja, asuhan keperawatan

Kutip artikel ini: Mastini, P., Suryadhi, N.T., Suryani, A. 2015. Hubungan Tingkat Pengetahuan, Sikap, Beban Kerja Perawat dengan Kelengkapan Dokumentasi Asuhan Keperawatan di IRNA IGD RSUP Sanglah Denpasar. Public Health and Preventive Medicine Archive 3(1): 40-43. D0I:10.15562/ phpma.v3i1.85 


\section{PENDAHULUAN}

Dokumentasi asuhan keperawatan adalah pencatatan setiap kegiatan asuhan keperawatan yang diberikan oleh perawat kepada setiap pasien. ${ }^{1}$ Dokumentasi tesebut sangat penting untuk merencanakan, melaksanakan dan evaluasi asuhan keperawatan. Dokumentasi asuhan keperawatan dimulai sejak pasien dirawat sampai dinyatakan pulang atau keluar dari ruang perawatan. Semua kegiatan asuhan keperawatan akan tercatat pada rekam medis penderita. Berbagai dampak ketidaklengkapan dokumen meliputi permasalahan administrasi, keuangan, pendidikan, penelitian, informasi serta hukum. ${ }^{1}$

Di ruang Rawat Inap Instalasi Gawat Darurat Rumah Sakit Umum Pusat (IRNA RSUP) Sanglah Denpasar terjadi peningkatan jumlah dokumen keperawatan yang tidak lengkap dari tahun ketahun. Hal ini berdampak terhadap pelayanan informasi rumah sakit secara menyeluruh. ${ }^{2}$ Rumah Sakit Umum Pusat Sanglah Denpasar telah berupaya untuk mengatasi masalah tersebut dengan menambah tenaga keperawatan sehingga beban kerja perawat dapat diturunkan. Namun upaya tersebut belum menunjukkan hasil yang optimal dimana dokumentasi asuhan keperawatan yang tidak lengkap tetap tinggi. Ruang Rawat Inap Instalasi Gawat Darurat Rumah Sakit Umum Pusat Sanglah Denpasar merupakan salah satu unit pelayanan terdepan di Rumah Sakit Umum Pusat Sanglah Denpasar yang mengalami ketidaklengkapan pada pendokumentasian asuhan keperawatan. Berdasarkan hasil pengamatan, rekam medis yang tidak lengkap di Ruang Rawat Inap Instalasi Gawat Darurat Rumah Sakit Umum Pusat Sanglah Denpasar rata-rata berjumlah 19 rekam medis per bulan. ${ }^{3}$

Hasil penelitian sebelumnya menunjukkan bahwa peningkatan dokumentasi asuhan keperawatan yang tidak lengkap berhubungkan dengan beberapa faktor seperti latar belakang pendidikan, lama masa kerja, beban kerja, pengetahuan dokumentasi, keterampilan dan beberapa faktor lain.4-6 Penelitian lain juga menemukan bahwa pengetahuan tenaga medis dan paramedis umumnya masih rendah terhadap pengisian dan pemanfaatan rekam medis. ${ }^{7}$

Sampai saat ini, perawat di Ruang Rawat Inap Instalasi Gawat Darurat Rumah Sakit Umum Pusat Sanglah Denpasar belum pernah mendapatkan pelatihan pengisian rekam medis yang lengkap dan benar, tetapi hanya dalam bentuk sosialisasi di masing-masing ruang rawat inap. Disamping itu, perbandingan jumlah perawat di Ruang Rawat Inap Instalasi Gawat Darurat Rumah Sakit Umum Pusat Sanglah Denpasar dengan pasien masih jauh dari seharusnya yaitu 1:5, dimana idealnya adalah $1: 1 .^{8}$ Selain itu sebagian besar perawat di RSUP Sanglah mempunyai masa kerja $\leq 10$ tahun.

Berdasarkan uraian di atas maka penelitian ini ditujukan untuk mengetahui hubungan antara pengetahuan, sikap dan beban kerja perawat dengan kelengkapan pendokumentasian asuhan keperawatan di Ruang Rawat Inap Instalasi Gawat Darurat Rumah Sakit Umum Pusat Sanglah Denpasar.

\section{METODE}

Desain penelitian ini adalah cross sectional dengan subyek penelitian semua perawat yang bertugas di Ruang Rawat Inap Instalasi Gawat Darurat Rumah Sakit Umum Pusat Sanglah Denpasar berjumlah 76 orang. Pengumpulan data dilakukan pada Bulan Mei-Juni 2013. Setiap perawat yang dipilih sebagai sampel diberikan informed consent untuk persetujuan berpartisipasi dalam penelitian. Selanjutnya setiap perawat diwawancarai untuk mendapatkan data mengenai tingkat pengetahuan, sikap dan beban kerja perawat. Data tentang kelengkapan pendokumentasian asuhan keperawatan didapatkan dengan cara melakukan observasi terhadap kelengkapan pendokumentasian berdasarkan terisinya semua item pada formulir rekam medis. Data hasil penelitian dianalisis secara deskriptif yaitu untuk mengetahui gambaran karakteristik subjek yaitu umur, jenis kelamin, pendidikan, masa kerja dan status pegawai. Analisis bivariat dan multivariat dilakukan untuk mengetahui hubungan antara pengetahuan, sikap dan beban kerja perawat dengan kelengkapan pengisian dokumen asuhan keperawatan.

\section{HASIL}

Sebanyak 48,6\% perawat di Ruang Rawat Inap Instalasi Gawat Darurat Rumah Sakit Umum Pusat Sanglah Denpasar berusia antara 22-29 tahun, $67,1 \%$ jenis kelamin perempuan, 88,2\% berpendidikan DIII keperawatan, 63,1\% dengan masa kerja $\leq 10$ tahun dan $76,3 \%$ berstatus pegawai negeri sipil (Tabel 1).

Pada Tabel 2 terlihat bahwa 57,9\% perawat mempunyai tingkat pengetahuan kurang, $51,3 \%$ mempunyai sikap negatif terhadap pendokumentasian asuhan keperawatan dan $61,8 \%$ mempunyai beban kerja sedang sampai berat. Berdasarkan hasil analisis bivariat didapatkan ada perbedaan yang bermakna pada proporsi perawat yang tingkat pengetahuannya baik dengan yang berpengetahuan kurang dengan kelengkapan dokumentasi asuhan keperawatan yaitu $84,4 \%$ vs $59,1 \%(\mathrm{p}=0,018)$. Perawat yang 
Tabel 1 Distribusi responden berdasarkan umur, jenis kelamin, pendidikan, masa kerja dan status pegawai

\begin{tabular}{ll}
\hline Variabel & $\mathbf{n}(\%)$ \\
\hline Umur (tahun) & $37(48,5)$ \\
$22-29$ & $27(35,5)$ \\
$30-37$ & $12(15,7)$ \\
$38-45$ & \\
Jenis kelamin & $25(32,9)$ \\
Laki-laki & $51(67,1)$ \\
Perempuan & \\
Pendidikan & $67(88,2)$ \\
DIII Kep & $9(11,8)$ \\
S1 Kep & \\
Masa kerja (tahun) & $48(63,1)$ \\
$\leq 10$ & $28(36,8)$ \\
$\geq 11$ & \\
Status pegawai & $58(76,3)$ \\
PNS & $18(23,7)$ \\
Kontrak &
\end{tabular}

Tabel 2 Hasil analisis bivariat variabel tingkat pengetahuan, sikap, beban kerja perawat dengan kelengkapan pendokumentasian asuhan keperawatan di IRNA IGD RSUP Sanglah Denpasar

\begin{tabular}{lcccc}
\hline & \multicolumn{2}{c}{$\begin{array}{c}\text { Kelengkapan dokumentasi } \\
\text { asuhan keperawatan }\end{array}$} & \\
\cline { 2 - 3 } Variabel & $\begin{array}{c}\text { Lengkap } \\
\mathbf{n}(\%)\end{array}$ & $\begin{array}{c}\text { Tidak lengkap } \\
\mathbf{n}(\%)\end{array}$ & $\begin{array}{c}\text { Total } \\
\mathbf{n}(\%)\end{array}$ & Nilai p \\
\hline $\begin{array}{l}\text { Pengetahuan } \\
\quad \text { Baik }\end{array}$ & $27(84,4)$ & $5(15,6)$ & $32(42,1)$ & 0,018 \\
$\quad$ Kurang & $26(59,1)$ & $18(40,9)$ & $44(57,9)$ & \\
Sikap & & & & \\
$\quad$ Positif & $30(81,1)$ & $7(18,9)$ & $37(48,7)$ & 0,036 \\
$\quad$ Negatif & $23(59,0)$ & $16(41,0)$ & $39(51,3)$ & \\
Beban Kerja & & & & \\
$\quad$ Ringan & $19(65,5)$ & $10(34,5)$ & $29(38,2)$ & 0,529 \\
$\quad$ Sedang-berat & $34(72,3)$ & $13(27,7)$ & $47(61,8)$ & \\
\hline
\end{tabular}

Tabel 3 Hasil analisis multivariat variabel pengetahuan dan sikap dengan kelengkapan pendokumentasian asuhan keperawatan di IRNA IGD RSUP Sanglah Denpasar

\begin{tabular}{lccc}
\hline Variabel & Adjusted OR & 95\%Cl & Nilai p \\
\hline Tingkat pengetahuan & 3,7 & $1,2-11,5$ & 0,022 \\
Sikap & 3,0 & $1,1-8,4$ & 0,196 \\
\hline
\end{tabular}

bersikap positif sebanyak $81,1 \%$ melaksanakan dokumentasi asuhan keperawatan secara lengkap sedangkan yang bersikap negatif hanya 59,0\% $(\mathrm{p}=0,036)$. Dalam penelitian ini tidak dijumpai adanya perbedaan yang bermakna antara beban kerja dengan kelengkapan dokumentasi asuhan keperawatan. Pada perawat yang mempunyai beban kerja sedang-berat $72,3 \%$ melaksanakan dokumentasi secara lengkap dan yang mempunyai kerja ringan sebesar $65,5 \%(\mathrm{p}=0,529)$.

Pada Tabel 3 disajikan hasil analisis mulivariat dengan metode regresi logistik antara variabel pengetahuan dan sikap dengan kelengkapan pendokumentasian asuhan keperawatan dimana adjusted $\mathrm{OR}$ tingkat pengetahuan diperoleh sebesar 3,7 (95\%CI: 1,2-11,5) dan sikap dengan adjusted OR sebesar 3,0 (95\%CI: 1,1-8,4).

\section{PEMBAHASAN}

Hasil penelitian ini menunjukkan bahwa pengetahuan yang baik secara statistik memiliki hubungan yang bermakna dengan kelengkapan pengisian dokumen asuhan keperawatan $(\mathrm{OR}=3,7$; 95\%CI: 1,2-11,5).

Penelitian ini sejalan dengan penelitian yang dilaksanakan oleh Lukman (2002) yang menunjukkan bahwa ada hubungan antara pengetahuan dan motivasi dengan perilaku perawat dalam pendokumentasian. ${ }^{4}$ Hasil penelitian ini juga sejalan dengan teori yang menyatakan bahwa perilaku yang didasari pengetahuan akan lebih langgeng daripada perilaku yang tidak didasari oleh pengetahuan. ${ }^{9}$ Namun peningkatan pengetahuan tidak selalu berdampak pada perubahan perilaku. Beberapa faktor yang mempengaruhi perilaku seseorang adalah pengetahuan dan sikap, namun pembentukan perilaku juga dipengaruhi oleh banyak faktor yang sangat kompleks. Individu yang mempunyai pengetahuan yang baik akan memiliki sikap yang positif dan adanya sikap yang positif akan menumbuhkan motivasi untuk meningkat kan kinerja. ${ }^{9}$ Perilaku merupakan hasil atau resultante antara stimulus atau faktor ekternal dengan respon atau faktor internal dalam subjek atau orang yang berperilaku tersebut. Dengan perkataan lain perilaku seseorang atau subjek dipengaruhi atau ditentukan oleh banyak faktor baik dari dalam maupun dari luar subjek. Faktor-faktor yang mempermudah terjadinya perilaku seseorang adalah pengetahuan, sikap dan perubahan perilaku. ${ }^{9}$

Perubahan perilaku diawali dengan adanya perubahan pengetahuan terhadap kelengkapan pendokumentasian asuhan keperawatan dan selanjutnya akan muncul sikap untuk melakukan kelengkapan pengisian dokumen asuhan keperawatan di Ruang Rawat Inap Instalasi Gawat Darurat Rumah Sakit Umum Pusat Sanglah Denpasar. 
Dalam penelitian ini tidak dijumpai adanya perbedaan yang bermakna antara beban kerja perawat di Ruang Rawat Inap Instalasi Gawat Darurat Rumah Sakit Umum Pusat Sanglah Denpasar dengan kelengkapan dokumentasi asuhan keperawatan. Hal ini kemungkinan karena semua perawat di Ruang Rawat Inap Instalasi Gawat Darurat Rumah Sakit Umum Pusat Sanglah Denpasar mempunyai beban kerja yang hampir sama.

Berdasarkan hasil penelitian ini disarankan bahwa untuk meningkatkan kelengkapan dokumentasi asuhan keperawatan diperlukan upaya-upaya untuk meningkatkan pengetahuan perawat baik dalam bentuk pelatihan maupun upaya peningkatan pengetahuan lainnya. Penelitian ini hanya dilaksanakan di Ruang Rawat Inap Instalasi Gawat Darurat Rumah Sakit Umum Pusat Sanglah Denpasar, dan karena itu hasil penelitian tidak bisa digeneralisir pada semua perawat di RSUP Sanglah atau rumah sakit lainnya.

\section{SIMPULAN}

Kelengkapan pendokumentasian asuhan keperawatan di Ruang Rawat Inap Instalasi Gawat Darurat Rumah Sakit Umum Pusat Sanglah Denpasar secara bermakna dipengaruhi oleh tingkat pengetahuan dan sikap perawat.

\section{UCAPAN TERIMA KASIH}

Ucapan terima kasih kami sampaikan kepada Direktur Rumah Sakit Umum Pusat Sanglah
Denpasar yang telah memberikan ijin penelitian serta semua rekan di unit rawat inap yang membantu pelaksanaan penelitian ini sampai selesai serta seluruh perawat yang berpartisipasi dalam penelitian ini.

\section{DAFTAR PUSTAKA}

1. Gemala RH. Pedoman Manajemen Informasi Di Pelayanan Kesehatan. Jakarta: Universitas Indonesia Press; 2010.

2. Atanay RS. Analisis Faktor-faktor yang Mempengaruhi Kinerja Perawat Dalam Melaksanakan Asuhan Keperawatan di RS Umum Fak-Fak Semarang. Fak. Kedokteran UNDIP; 2008.

3. RSUP Sanglah Denpasar. Laporan Tahunan Rumah Sakit Umum Pusat Sanglah Denpasar. Denpasar Bali; 2012.

4. Lukman. Hubungan Pengetahuan dan Motivasi dengan Perilaku Perawat dalam Pelaksanaan Pendokumentasian. Salatiga: BPRSUD; 2002.

5. Maheni. Hubungan Beban Kerja Perawat dengan Pendokumentasian Proses Asuhan Keperawatan (Skripsi); 2010.

6. Agus SR. Hubungan Antara Pengetahuan tentang Peraturan Rekam Medis dengan Kelengkapan Dokumentasi Keperawatan (Tesis). Yogyakarta: Universitas Gajah Mada; 2010.

7. Herdiansyah. Hubungan Antara Pengetahuan dan Sikap Perawat terhadap Kepatuhan Dokumentasi Asuhan Keperawatan di RSUD Muntilan ruang rawat inap Kabupaten Magelang (Tesis). Yogyakarta: UGM; 2011.

8. Isti H. Dokumentasi Keperawatan. Yogyakarta: Mitra Cendikia Press; 2009.

9. Notoatmodjo S. Pendidikan dan Perilaku Kesehatan. Jakarta: Rineka Cipta; 2003.

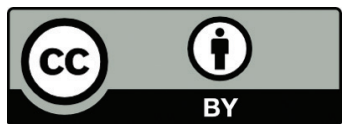

This work is licensed under a Creative Commons Attribution 